\title{
News repertoires and information behavior in Austria-What is the role of social inequality?
}

\author{
Dimitri Prandner $\cdot$ Christoph Glatz
}

Received: 15 May 2020 / Accepted: 4 September 2020 / Published online: 24 November 2020

(C) The Author(s) 2020, corrected publication 2020

\begin{abstract}
The changes in the global mediascape have had a tremendous impact on societal news flows. Using data from the Social Survey Austria 2018 and a quantitative application of the media repertoire approach, the article illustrates how information behavior and news seeking relate to social status, political orientation and sociodemographics. The results confirm that the developments in Austria-often referred to as a representative of a traditional media landscape-are mostly in line with international trends, as new media have been added to the media repertoires of approximately two-thirds of the sample. Effects tied to social inequality generally match previous assumptions: Higher educational achievements and income lead to more diversified news repertoires. Additionally, the overall structure of the data indicates that the online-only users are still a small minority, consisting of younger individuals who are less likely to work and more likely to vote for left-wing parties.
\end{abstract}

\footnotetext{
Anmerkung The data used for this article is available as a scientific use file via AUSSDA — the Austrian Social Science Data Archive. Source: Hadler, Markus, Franz Höllinger, and Johanna Muckenhuber. 2019. "Social Survey Austria 2018 (SUF edition)". https://doi.org/10.11587/ERDG3O, AUSSDA Dataverse, V3, (Last access: 30 January 2020).
}

Electronic supplementary material The online version of this article (https://doi.org/10.1007/ s11614-020-00433-w) contains supplementary material, which is available to authorized users.

\footnotetext{
D. Prandner $(\bowtie)$

Department of Politics and Sociology, University of Salzburg, Rudolfskai 42, 5020 Salzburg, Austria E-Mail: dimitri.prandner@jku.at

Empirical Social Research Unit, Johannes Kepler University Linz, Altenbergerstraße 69, Linz, Austria

C. Glatz

Center for Social Research, Karl-Franzens-Universität Graz, Universitätsstraße 15/G4, 8010 Graz, Austria

E-Mail: Christoph.glatz@uni-graz.at
} 
Keywords Media repertoires · Information behavior - Social Survey Austria · Austria

\section{Nachrichtenrepertoires und Informationsverhalten in Österreich - Welche Rolle spielt die soziale Ungleichheit?}

Zusammenfassung Die Veränderungen in der globalen Medienlandschaft haben einen enormen Einfluss auf den Nachrichtenfluss in Gesellschaften gehabt. Der Beitrag nutzt die Daten des Sozialen Survey Österreich 2018 und einen quantitativen Medienrepertoire-Ansatz, um zu veranschaulichen, wie Informationsverhalten und Nachrichtensuche mit sozialem Status, politischer Orientierung sowie Soziodemografie in Zusammenhang stehen. Die Ergebnisse zeigen, dass Österreich - obwohl es meist als Vertreter einer traditionellen Medienlandschaft klassifiziert wird - großteils internationalen Trends folgt. Zwei Drittel der Befragten haben inzwischen OnlineMedien sowie soziale Medien in ihr Medienrepertoire aufgenommen. Die Auswirkungen sozialer Ungleichheit auf das Informationsverhalten entsprechen in weiten Bereichen bisherigen wissenschaftlichen Erkenntnissen: So gehen höheres Bildungsniveau und Einkommen mit einem vielfältigeren Nachrichtenrepertoire einher. Die Daten weisen außerdem darauf hin, dass die reinen Online-Nutzer*innen immer noch eine kleine Minderheit darstellen. Diese Gruppe setzt sich weitestgehend aus jüngeren Personen zusammen, die mit geringerer Wahrscheinlichkeit erwerbstätig sind und eher für linkspolitische Parteien stimmen.

Schlüsselwörter Medienrepertoires · Informationsverhalten · Sozialerhebung Österreich · Österreich

\section{Changing media environments and information seeking}

The last 25 years have changed the global mediascape substantially. While the late 20th century media environments included broadcasting, newspapers and media organizations' websites, the early 21 st century has been defined by the rise of social media (Fletcher and Nielsen 2017). The process of how news can be accessed has changed profoundly as communication technology matured (Levy and Newman 2014; Livingstone 2013; Song et al. 2019). Thus, platforms, such as Facebook or Instagram, and messaging applications, such as WhatsApp or Signal, attract a lot of attention regarding information behavior and media consumption. Social media are currently an integral part of the so-called 'high choice media environments' that force consumers to divide their limited amount of time between a manifold of news offerings (Eisenegger 2019; Gil de Zúñiga et al. 2017; Lindell and Hovden 2018; Nielsen and Ganter 2018; Song et al. 2019).

Despite the initial hope that this expansion of the mediascape may lead to a more active, engaged, deliberated and more equal society, empirical data could not confirm this (Aalberg et al. 2013; Wolfsfeld et al. 2016). Moreover, a number of studies in recent years from the field of audience research have highlighted that the rela- 
tion between social inequalities and how informed individuals are in high choice media environments have become more pronounced (Kalogeropoulos and Nieslon 2018, p. 1; Lindell 2018, p. 3044). Whereas those who are educated and have access to financial and social resources may profit from a diversified media environment-gaining access to information and news not available previously-those already deprived do not profit to the same extent (Kalogeropoulos and Nieslon 2018; Lindell 2018; Prior 2005). This creates a potential vicious cycle: Inequalities increase as those already deprived of information are more likely to experience other forms of inequality as well because they may make less informed choices (Tichenor et al. 1970; Lindell 2018). Furthermore, traditional cleavages that have long shaped news diets, such as political orientation and social integration, are still known to have a large influence on how individuals stay informed about society (Dilliplane 2011; Trilling and Schönbach 2013).

Building upon these statements, we use data from the Austrian Social Survey of 2018 (Sozialer Survey Österreich, SSÖ; Hadler, Höllinger, and Muckenhuber 2019) to test if and how news seeking - and, thus, an uneven distribution of information-relates to social inequality.

Consequently, two research questions will be explored:

- How do Austrians seek out news in the current media landscape?

- Is social inequality influencing their news-seeking behavior?

Sect. 2 gives an overview of relevant concepts and the resulting hypotheses. The dataset and methods used are introduced in Sect. 3. The results are presented and discussed in Sect. 4. Sect. 5 closes the article with some specific takeaways and generalized remarks.

\section{The relation between high choice media environments and social inequalities}

Despite far-reaching changes influencing the global mediascape, Austria is typically classified as a country with a very traditional news environment (Song et al. 2019, p. 3). Research on the Austrian media system typically highlights the consolidated (print-)newspaper market and the influential public service broadcaster, the $O R F$ (e.g. Kirchhoff and Prandner 2016; Magin and Stark 2011). The dominant Neue Kronen Zeitung-commonly known as Krone-was shown to reach 27\% of all Austrians 14 years and older in 2018, a reach unrivaled in Europe, and the TV offerings of the public service broadcaster ORF had a market share of $32 \%$ (see MediaAnalyse 2019; Sparviero and Trappel 2019).

Those features can also be corroborated via the individual-level data on media usage available. Both highly specialized surveys, such as the Reuters Study on Digital News (DNR) or the Austrian National Election Study (AUTNES), and general population surveys, including the SSÖ 2016, confirm that Austrians depend on legacy media, such as the TV and newspapers, to stay informed (Sparviero and Trappel 2019, p. 70; Prandner 2019, p. 418). 
However, recent literature concerning the topic hints at a cohort-effect (Prandner 2019 , p. 424), which should become more poignant over time. There seems to be a relevant gap between the younger-often referred to as digital-born who grew up with online and social media-and older generations - those who were already older when the mediascape expanded-in the rest of the world when it comes to online and social media usage (Palfrey and Gasser 2011; Schulz et al. 2019). The existing data from the Austrian Media Analysis and the survey data mentioned already illustrate that younger Austrians use online and social media more often when seeking information, even if they do not rely on it entirely (Prandner 2019, p. 423; Stark 2007, p. 151). In this field, the online presence of the center-left newspaper Der Standard and the tabloid Heute have a reach comparable to the website of the Krone, counting more than 5 million unique users per quarter (OeWA 2019). However, this is only half the reach of the $O R F$ 's web presence, which sees more than 10 million unique users per quarter (OeWA 2019), a number exceeding Austria's population which is currently at nearly 9 million. This illustrates that changes in the mediascape and demography may alter the information flow in the country, despite being classified as a traditional news environment.

Furthermore, research on Austria shows that there might be additional societal fault lines influencing media usage patterns (Prandner 2019, p. 424; Schmuck et al. 2016, p. 93; Trilling and Schönbach 2013, p. 946), pointing towards the relevance of social inequalities in media usage and information retrieval. A sentiment that echoes a statement by Tichenor et al. (1970, p. 159), where they hypothesized that an influx of mass media information will be mostly used by segments of the population who already have a higher socioeconomic status. They are able to acquire information via various means, while those of lower status will have only limited interest or means to access the information.

The following Sect. 2.1 addresses how news consumption may be discussed within a quantitative framework, tying into the established concept of media repertoires (Bjur et al. 2014; Hasebrink and Domeyer 2012; Wolfsfeld et al. 2016). Sect. 2.2 explores the relationship between news consumption and social inequalities (e.g. Kalogeropoulos and Nielsen 2018; Lindell 2018), while 2.3 takes additional explanations into account. The corresponding hypotheses are presented in Sect. 2.4.

\subsection{News seeking in high choice media environments}

The rapid expansion of media environments during the late 20th and early 21 st century has resulted in a wide range of new questions (Livingstone 2013) mainly on how individuals and societies alike stay informed about current affairs and events (Livingstone 2013; Van Dijck 2009). In the past, people who were watching television or listening to the radio for reasons that had little to do with news were incidentally exposed to information about current developments (Fletcher and Nielsen 2017; Neuman et al. 1992). Nowadays, the traditional editorial news selection-which is still the foundation of coordinated, linear programming - and journalistic gatekeeping have been seemingly replaced by highly personalized news flows from digital media sources, for example, social media (Giglietto et al. 2019, p. 629). Content is filtered, prioritized and tailored to match the (perceived) interests and needs of users 
(Stroud 2011). Social media focuses on connecting users, helping them form communities, sharing their content and engaging with peers (Hille and Bakker 2013). However, straight to the point: Social media was in no way designed to provide societies with relevant news.

Therefore, it comes as no surprise that the omnipresence of online and social media has led to different forms of unease about societal information flows. On the one hand, highly contested and often misleading buzzwords, such as echo chambers, filter bubbles and fake news, have become increasingly common (Giglietto et al. 2019; Prandner 2019; Sobieraj and Berry 2011), on the other hand, many political and economic actors have seized the opportunity to restructure their communication policies, hence, also changing how information flows throughout society (Hepp and Hasebrink 2014; Livingstone 2013). In the case of Austria, this has been discussed extensively as the populist far-right Austrian Freedom Party (FPOE) is not only well versed in the use of new media (Esser et al. 2017, p. 375)-maintaining an extensive online presence on Facebook, Twitter and YouTube-but also antagonizing traditional mass media, especially the public service broadcaster $O R F$ and quality press, such as Der Standard or Der Falter (Engesser et al. 2017, p. 1113; Schmuck et al. 2016, p. 98).

Thus, what kind of media is consumed by whom and in which combinations moves into focus (Schmuck et al. 2016; Stark 2007), building the foundation for the two central questions stated at the end of the introduction. The concept of media repertoires will be used to discuss how Austrians seek out news in today's media environments (Hasebrink and Domeyer 2012). This is a systematic approach that describes the actual media consumption of an individual while acknowledging that the emergence of new media platforms makes cross-media use far more seamless but also more complicated than before (Bjur et al. 2014). Representatives of the concept argue that each individual uses a particular combination of sources to learn about the world (Wolfsfeld et al. 2016). The more sources, the richer the repertoire and the better informed the particular individual (Hasebrink and Popp 2006). Current international research highlights the inherent difference between 'news seeker' and 'news avoider' (Elvestad et al. 2014). While news seekers are understood as the part of the population that is actively searching for information, the avoiders are those who are not engaging with news media (Schneider and Eisenegger 2019; Strömbäck 2017) either intentionally, for example, because of news overload or low trust in news, or unintentionally, for example, individuals who prefer non-news media content (Fletcher and Nielsen 2017; Skovsgaard and Andersen 2020).

However, mainly qualitative studies and highly specialized surveys which deal mostly with media usage employ this repertoire approach (e.g. Da Silva et al. 2017; Hasebrink and Domeyer 2012; Newman et al. 2018; Schneider and Eisenegger 2019; Schulz et al. 2019). Reasons for this are tied to the fact that the initial use of the repertoire approach focused on the audience's choice of media to get specific information (Reagan 1996), forcing researchers to obtain data on specific offers or brands a recipient may use, i.e. if someone reads, for example, the New York Times or the Sun or watches Fox News or CNN. A prominent international example of this strategy is the highly specialized Reuters DNR survey. It covers the media usage aspect via the following questions: "Which of the following brands have you used 


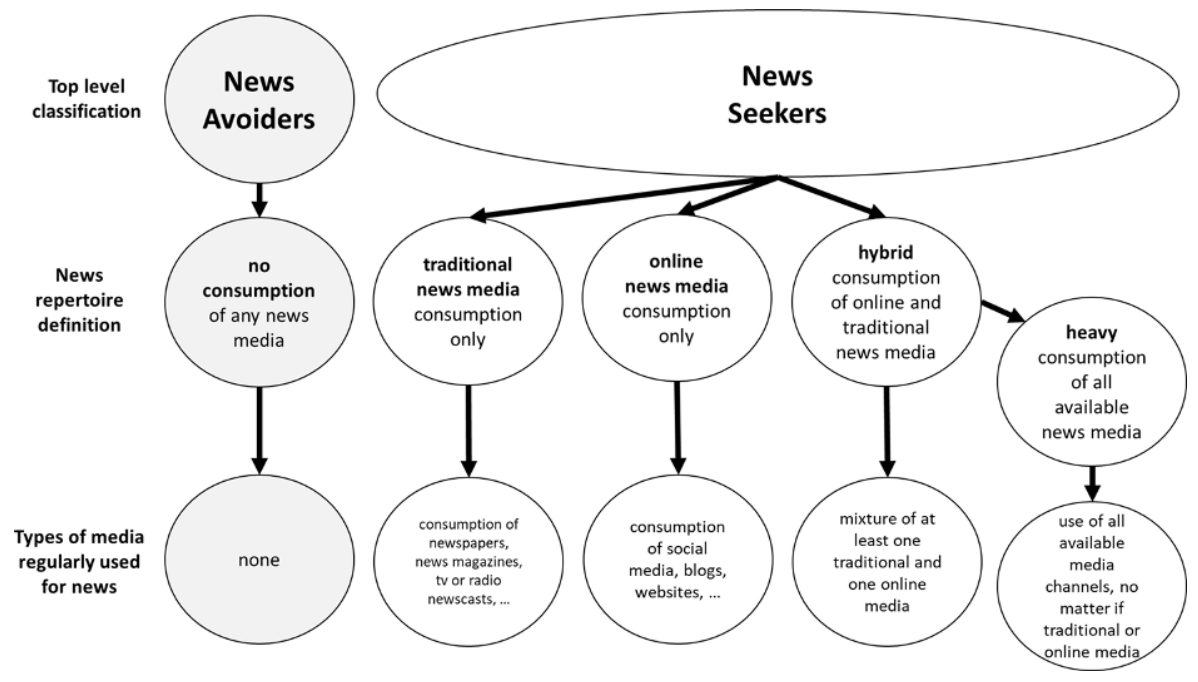

Fig. 1 Classification and description of news seekers and news avoiders

to access news offline/online in the last week?" (Schulz et al. 2019, p. 12). Hence, information is based on long lists of dichotomous variables that provide respondents with the chance to give answers that reflect the country's complete media offerings on a title by title basis.

However, this is not a feasible approach for multi-topic, general population surveys, such as the European Social Survey (ESS), the General German Social Survey (ALLBUS) or the International Social Survey Programme (ISSP), where the number of items and time spent on a specific topic during the interview is strictly limited.

Despite this limitation, researchers use the concept as a background for structuring data gained via such general population surveys (e.g. Elvestad et al. 2014; Prandner 2019; Wolfsfeld et al. 2016). While not including media titles, they often include information on the usage of media channels, for example, broadcasting, newspapers and online or social media. Thus, the more general survey programs provide enough information to distinguish groups of individuals who use particular information sources and combinations of them. In some cases, it is even possible to go beyond a top-level dichotomy of news avoiders and news seekers, helping one to understand different types of media users (Prandner 2019; see also Fig. 1).

The repertoire approach allows the tracking of phenomena, such as media convergence, or the importance of new technologies (e.g. Yuan (2011) for China or Wolf and Schnauber (2015) for Germany), making otherwise problematic international comparisons possible (Hallin and Mancini 2004; Trilling and Schönbach 2013).

Furthermore, despite lacking the thick descriptive power of in-depth interview data, which helped, for example, Da Silva et al. (2017) identify seven very specific Portuguese news repertoire types that included detailed nuances regarding the audience's media choices, quantitative repertoire approaches are suitable for gaining insight into societal consequences of information behavior on a larger scale (e.g. Prandner 2019; Schneider and Eisenegger 2019). A prominent example of this is the 
work by Eisenegger and Schneider (2016), who developed a typology for Switzerland classifying six repertoires and arguing for the substitution of the term 'news avoiders.' They propose 'news deprived,' highlighting the danger of the aforementioned societal and political risks if a part of the population is not informed about current developments (Edgerly et al. 2018; Eisenegger and Schneider 2016; Skovsgaard and Andersen 2020). Projects such as the Reuters Study on Digital News pay tribute to this, as they ask their respondents if they have intentionally decided to avoid news (Kalogeropoulos et al. 2017). However, compared to actual information of usage, this question is vulnerable to situational or periodic changes (Skovsgaard and Andersen 2020; Webster 2014) and, thus, is seldom included in the formation of repertoires.

Other common groupings in the quantitative field of news repertoire research include strictly traditional news repertoires, composed of, for example, combinations of printed newspapers, magazines, radio and television broadcasting, and strictly online-based repertoires, made up of online sources including social media. Next, there are hybrid repertoires, which include at least one online source and one traditional news source. If someone uses all types of media to inform themselves, their repertoire is classified as a general heavy use of news media (e.g. Trilling and Schönbach (2013, p. 938) used this term in their media title driven analysis for Austria). Strictly speaking, heavy users are a subgroup of the hybrid repertoire. However, they are typically defined by the fact that they are using a very broad range of available media and do not show specific preferences in their media choice. They are characterized by the large amount of exposure rather than what news they are searching out (Trilling and Schönbach 2013, p. 938).

Most of the current studies using a repertoire approach highlight that the study subjects developed distinct news repertoires that include not only traditional, social or online media but also combinations of them (in addition to the examples mentioned previously, further examples include Strömbäck (2017) for Sweden and Taneja et al. (2012) for the United States). This is also true for Austria, although up to 2016, its population was mostly dependent on traditional media for information (Prandner 2019, p. 424; Trilling and Schönbach 2013, p. 938). Nevertheless, these results need to be seen in context. The field work of the utilized survey was accompanied by a public discussion about potential fake news in Austria during the presidential election when fake claims concerning the health and behavior of the now President Alexander Van der Bellen spread via social media (Prandner 2019, p. 420; Sparviero and Trappel 2017, p. 55). Data concerning how the debate on fake news influenced information behavior and, thus, media repertoires is currently not available.

The empirical part of this article attempts to identify distinct news repertoires in Austria in 2018. Based on prior research, we expect a traditional news repertoire to be most common. Strictly online-based news repertoires are expected to be a marginal phenomenon. 


\subsection{Social inequality as a determinant of information behavior}

Over the last few decades, the assumption has been common that the emergence of high choice media environments will lead to a better-informed society, which has more accessible news than ever before (Chadwick et al. 2016). Those theses were built upon audience research concluding that new media leads to an expansion of news sources and not a substitution (Hasebrink et al. 2015, p. 450). Alternatively, and more positively formulated: The introduction of new media types should result in an additive effect on the news repertoires of individuals (Seufert and Wilhelm 2013).

As stated earlier, previous research shows that these assumptions may be-at least partially - correct for Austria. The new media offerings are primarily used in an additive way and are seldom the singular source of information on contemporary affairs (Prandner 2019, p. 420). However, researchers concluded that incidental exposure to news and information on an international level becomes increasingly unlikely, while selective exposure becomes more prevalent (Bennett and Iyengar 2008; Hasebrink et al. 2015; Lindell 2018; Ohlsson et al. 2017). It has been argued that in high-choice environments, those most interested get more news and engage more but those least interested get less news and become less engaged in society (Kalogeropoulos and Nielsen 2018; Prior 2005).

Accordingly, recent publications highlight that studies should acknowledge the importance of social inequalities-which have been long-discussed influences on media consumption patterns (Kalogeropoulos and Nielsen 2018; Ohlsson et al. 2017). Furthermore, it is argued that the emergence of new information and communication technologies and their use must be discussed in unison with social positioning and status (Hasebrink et al. 2015, p. 439; Schmuck et al. 2016, p. 98; Zillien and Hargittai 2009, p. 277). This statement can be traced back to at least the 1970s (Tichenor et al. 1970) but regains importance as social inequalities are on the increase in many Western European states (e.g. Carmo 2017; Kuhn et al. 2016). This includes Austria, where social fault lines have deepened over the last decade (e.g. Bacher et al. 2019). While the 'golden years' of the late 20th century were shaped by educational and economic expansion, social upward mobility and political stability, the citizens of today experience growing inequalities when it comes to wealth and education (Hofman 2016; Lynch 2019).

Relations between social position, inequalities and media repertoires have not only been discussed on a theoretical level. Studies consistently identify formal education and income as predictors for broad information repertoires. The less educated or financially worse off are at a higher risk of being less informed about society as they maintain smaller news repertoires (Lindell and Hovden 2018; Schmuck et al. 2016). Those arguments are tied to the fact that educational achievements coincide with a broader interest in society and information. A higher income allows individuals to buy devices necessary for media consumption and access to information sources, for example, subscription fees for newspapers or web pages (Kalogeropoulos and Nielsen 2018; Lindell 2018). The same holds true for employment status. Those who are integrated into the workforce to a larger extent have a need to stay informed about developments, although they—hypothetically—have less time to do 
so, thus, demanding different information strategies and patterns (Hasebrink and Popp 2006; Lindell 2018; Lindell and Hovden 2018).

\subsection{Social networks, social trust and political orientation as further determinants of information behavior}

In addition to social inequality itself, other-related-drivers for diverse media usage and, thus, broad news repertoires can be found in recent studies on social networks. The research teams Berner et al. (2013) and Li et al. (2017), after looking at specific subpopulations such as the elderly in Sweden or adolescents in Finland, respectively, concluded that strong social networks and social trust foster broad media usage. This information may also be key to understanding media repertoires as empirical studies have shown that those who are experiencing social inequality are often lacking in their social networks (Calvo-Armengol and Jackson 2004; Lin 2000). However, Media consumption patterns - as well as news seeking-have proven to vary strongly between different countries as the impact of technology is highly context-dependent (Levy and Newman 2014).

Finally, Kalogeropoulos et al. (2017, p. 9) showed in a six-country comparison (USA and five western European countries) that people with stronger ideological positions, for example, decisively right- or left-wing, are more likely to actively use social media in their information routines than people who are more centrist. This matches the findings from Lindell and Hovden (2018, p. 652), who argue that Europeans who believe in right-wing politics are more likely to reject mainstream media and traditional news sources. Esser et al. (2017, p. 375) pointed out for Austria that this should be especially evident within the group of right-wing voters- the FPOE. However, this argument is currently contested. Previous empirical research from Trilling and Schönbach (2013) could not confirm such an effect. In any case, a discussion of social inequalities and media use needs to take political orientation into account as studies show that the socially deprived are more likely to take on politically extreme positions (Han 2016).

We include an empirical analysis of the effects of social position and networks and political orientation on the media repertoires of individuals to consider all these factors.

\subsection{Assumptions and hypotheses based on recent findings}

Several hypotheses will be tested based on current findings and literature-see 2.1 through 2.3. This section and Table 1 give an overview of the effects expected.

In a nutshell, the main hypothesis will deal with social positions as an indicator of social inequality. In accordance with the literature (Kalogeropoulos and Nieslen 2018; Lindell and Hovden 2018; Schmuck et al. 2016; Tichenor et al. 1970), it is expected that those with a higher income, education, stronger workforce integration and perceived higher social status are more likely to use a broader range of media to inform themselves. 
H1a: Individuals with higher social positions are more likely to use hybrid repertoires.

H1b: Individuals with higher social positions are more likely to be heavy users.

Additional hypotheses build upon the theoretical arguments concerning media usage, social trust and political orientation. The statements of Berner et al. (2013) and Li et al. (2017) lead to the hypothesis that strong social networks and social trust have a significant impact on the inclusion of online and social media in one's news repertoire. As the results reported by Trilling and Schönbach (2013) conflict with the statement from Esser et al. (2017, p. 375), Kalogeropoulos et al. (2017, p. 9) and Lindell and Hovden (2018, p. 652) that individuals who identify with the far-right of the political spectrum are prone to cut out traditional mainstream media, we will test this assumption as well. We expect that FPOE voters are more likely to use an online-only news repertoire.

H2a: Individuals who show high social trust are more likely to use a hybrid news repertoire.

H2b: Individuals who show high social trust are more likely to be heavy users.

H2c: Individuals who have extensive social networks are more likely to be heavy users.

H3: Individuals who prefer the freedom party are more likely to have an onlineonly news repertoire.

Table 1 News repertoires and effects expected

\begin{tabular}{|c|c|c|c|c|c|}
\hline Hypothesis & Dimension & $\begin{array}{l}\text { Use of } \\
\text { a tradi- } \\
\text { tional news } \\
\text { repertoire }\end{array}$ & $\begin{array}{l}\text { Use of an } \\
\text { online-only } \\
\text { news reper- } \\
\text { toire }\end{array}$ & $\begin{array}{l}\text { Use of } \\
\text { a hybrid } \\
\text { news reper- } \\
\text { toire }\end{array}$ & $\begin{array}{l}\text { Heavy } \\
\text { use news } \\
\text { repertoire }\end{array}$ \\
\hline \multicolumn{6}{|c|}{ Main Hypothesis } \\
\hline \multirow{4}{*}{$\begin{array}{l}\mathrm{H} 1(\mathrm{a}+\mathrm{b}) \\
\text { Social } \\
\text { Position }\end{array}$} & Reported social status & & & + & + \\
\hline & Higher education & & & & \\
\hline & Higher income & & & & \\
\hline & Working hours & & & & \\
\hline \multicolumn{6}{|c|}{ Supporting Hypotheses } \\
\hline \multirow{3}{*}{$\begin{array}{l}\mathrm{H} 2 \\
(\mathrm{a}+\mathrm{b}+\mathrm{c}) \\
\text { Social } \\
\text { networks } \\
\mathrm{H} 3 \\
\text { Political } \\
\text { orientation }\end{array}$} & Social trust & & & + & + \\
\hline & $\begin{array}{l}\text { Extensive social } \\
\text { network }\end{array}$ & & & & \\
\hline & Political orientation & & $\begin{array}{l}+ \\
(\mathrm{FPOE})\end{array}$ & & \\
\hline $\begin{array}{l}\mathrm{H} 4 \\
\text { Age }\end{array}$ & Age in years & & + & & \\
\hline
\end{tabular}


Finally, whether age influences the news repertoire will be tested. As literature suggests, younger participants are likely to have an affinity for online and social media (Palfrey and Gasser 2011; Schulz et al. 2019).

H4: The younger the respondents, the more likely they are to use an online-only repertoire.

\section{The dataset and methods}

We use data gathered via the Austrian Social Survey (SSÖ) in 2018 to test the hypotheses proposed (Sect. 2.4). The $S S O ̈$ is a multi-topic questionnaire based on a random household sample of $n=1200$ Austrians. The survey was conducted with computer-assisted personal interviews during the second quarter of 2018. The national response rate was $51 \%$. The dataset and the method report with an elaborate description of the sample can be found in the Austrian Social Survey Data Archive (Hadler et al. 2019). We use combined post-stratification and design weights, adjusting for age, sex and education, for the descriptive and regression analysis.

Nevertheless, the multi-topic design is accompanied by a substantial advantage and a disadvantage for the study at hand, imposing specific limitations on the analysis:

- On the one hand, it provides a rich supplement of information not tied to media usage and, therefore, allows an exploration of a broader research agenda.

- On the other hand, it only provides an overview of media usage patterns and does not go in-depth (e.g. media titles). This limits the depth of the repertoires that can be defined.

The results have to be read accordingly as, for example, one finds quality and tabloid press, politically conservative and progressive-orientated content within the framework of newspapers. Hence, the analysis is concerned with discussing news channels and not news titles.

Linear regression models are calculated based on the assumptions outlined in Sect. 2 and the resulting hypothesis. We distinguish four news repertoires in detail:

1. Strictly traditional: Based on newspapers and/or television only.

2. Online-only: Based on online sources and social media only.

3. Hybrid: Includes at least one online and one traditional news source.

4. Heavy use: Characterized by the inclusion of all four survey news sources (TV, printed newspaper, and online and social media).

While from a statistical point of view, those models demand a logistic regression model, we decided to use a linear one as the hypothesis requires us to compare the independent variables within each model. The decrease in accuracy seems unproblematic as linear regression allows one to determine the overall variance explained at the level of the model and the relative contribution of each of the predictors to the total variance explained (Cohen 1968; Long and Freese 2006). We calculated the robust standard errors for each dependent variable to check for overestimation 
Table 2 Dependent variables

\begin{tabular}{lc}
\hline Variables/Question & $\begin{array}{l}\text { Percentage } \\
\text { (very often + often + sometimes) }\end{array}$ \\
\hline How often do you use the following media to inform & yourself about current developments? \\
... TV & 86.7 \\
... printed newspaper (hardcopy only) & 76.3 \\
... online media (Websites, etc.) & 44.3 \\
... social media (Facebook, Twitter, etc.) & 47.9 \\
\hline
\end{tabular}

(Andersen 2008, p. 4). We estimated p-values and, subsequently, significances based on these robust standard errors. SPSS V26 was used and HC3 was applied for the robust standard error procedure.

All three linear regression models use the traditional news repertoire as the reference category. It is coded with a 0 . The other three repertoires are coded accordingly to the model with a 1 .

Table 2 gives an overview of the variables used for building distinct news repertoires. Originally based on a five-point Likert scale (see also Fig. 1 in the following section), we decided to dichotomize the variables into dummy variables. Those who use the specific media very often, often or at least sometimes are coded with 1 and considered for inclusion into a specific repertoire. If someone uses the corresponding media rarely or never to inform themselves, they are coded with 0 . Based on this, four distinguishable repertoires could be calculated: Exemplarily, someone who uses TV very often but online media and social media only rarely would be classified as a traditional media user. Someone who uses TV often, the hardcopies of printed newspapers and social media sometimes but never online media would be a hybrid user. In comparison to more elaborate models - such as cluster analytics based on the use of individual media titles (Trilling and Schönbach 2013) — this approach was chosen because it is a better fit for the data available, while also going beyond the news avoiders and news seekers dichotomy (Elvestad et al. 2014).

The independent variables for the models are grouped into four distinct dimensions, matching the hypotheses.

Concerning the main hypothesis, dimension one (social position) includes the perceived social status of the interviewees, education, income and working hours. While the latter three are based on manifest variables, the one concerning social position is a factor made up of two variables: Measuring past and current social position.

According to hypothesis 2, dimension two (social networks) includes two indicators: a) A factor composed of two variables measuring general trust in others, i.e. whether others are prone to take advantage of them, and b) the number of social contacts one has on a regular weekday.

The third hypothesis is tested via acknowledged party preferences. Consequently, dummy variables for all ten parties that participated during the 2017 national elections were created. However, due to low case counts, we only include the people's party $(O E V P)$, the social democrats $(S P O E)$, the FPOE and the green party $(G R U E N E)$ in the regression models. Each of those were stated as the preferred 
Table 3 Independent and explanatory variables

\begin{tabular}{|c|c|c|c|c|c|}
\hline & & Variables/Question & $\begin{array}{l}\text { Scale and } \\
\text { Range }\end{array}$ & $\begin{array}{l}\text { Mean } \\
\text { (Median) } \\
\text { or } \\
\text { Percentage }\end{array}$ & St. Dev \\
\hline \multirow[t]{8}{*}{$\begin{array}{l}\text { Social } \\
\text { position }\end{array}$} & \multirow[t]{3}{*}{$\begin{array}{l}\text { Perceived } \\
\text { social } \\
\text { status }\end{array}$} & $\begin{array}{l}\text { In our society, there are } \\
\text { those who are on top, and } \\
\text { those who are at the bot- } \\
\text { tom, ... }\end{array}$ & \multicolumn{3}{|c|}{$\begin{array}{l}\text { (1 Factor extraction; var. expl.: } 73.7 \% \text {; } \\
\text { Eigenvalue: } 1.47 \text { ) }\end{array}$} \\
\hline & & $\begin{array}{l}\text { Where would you place } \\
\text { yourself today? }(n=1174)\end{array}$ & $\begin{array}{l}1 \text { (bottom) to } \\
10 \text { (top) }\end{array}$ & $5.82(6)$ & 1.45 \\
\hline & & $\begin{array}{l}\text { Where would you place } \\
\text { your family growing up? } \\
(n=1168)\end{array}$ & & $5.37(5)$ & 1.76 \\
\hline & \multirow[t]{2}{*}{ Education } & $\begin{array}{l}\text { Completed secondary educa- } \\
\text { tion (Matura; } n=1200 \text { ) }\end{array}$ & $\begin{array}{l}1 \text { (yes); } \\
0 \text { (no) }\end{array}$ & $15.4 \%$ & - \\
\hline & & $\begin{array}{l}\text { Completed tertiary education } \\
\text { (BA to } \mathrm{PhD} ; n=1200)\end{array}$ & & $12.5 \%$ & - \\
\hline & Income & $\begin{array}{l}\text { Individual net income in } € \\
\text { (self-reporting; } n=1200 \text { ) }\end{array}$ & $\begin{array}{l}0 \text { to } \\
7000 €\end{array}$ & $\begin{array}{l}1165.67 \\
(1291.52)\end{array}$ & 953.46 \\
\hline & $\begin{array}{l}\text { Working } \\
\text { hours }\end{array}$ & $\begin{array}{l}\text { Part-time (up to } 35 \mathrm{~h} \text { per } \\
\text { week; } n=1200 \text { ) }\end{array}$ & $\begin{array}{l}1 \text { (yes); } \\
0 \text { (no) }\end{array}$ & $15.7 \%$ & - \\
\hline & & $\begin{array}{l}\text { Full-time ( } 36 \text { or more hours } \\
\text { per week; } n=1200 \text { ) }\end{array}$ & $\begin{array}{l}1 \text { (yes); } \\
0 \text { (no) }\end{array}$ & $48.4 \%$ & - \\
\hline \multirow[t]{4}{*}{$\begin{array}{l}\text { Social } \\
\text { networks }\end{array}$} & \multirow[t]{3}{*}{$\begin{array}{l}\text { Social } \\
\text { trust }\end{array}$} & & \multicolumn{3}{|c|}{$\begin{array}{l}\text { (1 Factor extraction; var. expl.: } 62.1 \% \text {; } \\
\text { Eigenvalue: } 1.24)\end{array}$} \\
\hline & & $\begin{array}{l}\text { Do other people try to take } \\
\text { advantage of you or do they } \\
\text { try to be fair? }(n=1176)\end{array}$ & $\begin{array}{l}1 \text { (always take } \\
\text { advantage) to } \\
4 \text { (never take } \\
\text { advantage) }\end{array}$ & $\begin{array}{l}3.10 \\
(3)\end{array}$ & 0.75 \\
\hline & & $\begin{array}{l}\text { Generally speaking, do } \\
\text { you think people are to be } \\
\text { trusted? }(n=1194)\end{array}$ & $\begin{array}{l}1 \text { (trust no } \\
\text { one) to } \\
4 \text { (trust nearly } \\
\text { everyone) }\end{array}$ & $\begin{array}{l}2.59 \\
(3)\end{array}$ & 0.78 \\
\hline & $\begin{array}{l}\text { Social } \\
\text { network } \\
\text { size }\end{array}$ & $\begin{array}{l}\text { With how many people do } \\
\text { you interact on a regular } \\
\text { weekday? No matter the } \\
\text { type of contact }(n=1186)\end{array}$ & 2 to 100 & $\begin{array}{l}22.01 \\
(15)\end{array}$ & 24.29 \\
\hline \multirow{4}{*}{$\begin{array}{l}\text { Political } \\
\text { orienta- } \\
\text { tion }\end{array}$} & \multirow{4}{*}{$\begin{array}{l}\text { Party } \\
\text { prefer- } \\
\text { ence }\end{array}$} & $\begin{array}{l}\text { Green party (center-left to } \\
\text { left-wing) }\end{array}$ & $\begin{array}{l}1 \text { (yes); } \\
0 \text { (no) }\end{array}$ & $6.2 \%$ & - \\
\hline & & $\begin{array}{l}\text { Social democrats (center-left } \\
\text { to left-wing) }\end{array}$ & & $34.7 \%$ & - \\
\hline & & $\begin{array}{l}\text { People's party (center-right } \\
\text { to right-wing) }\end{array}$ & & $37.4 \%$ & - \\
\hline & & Freedom party (far-right) & & $21.7 \%$ & - \\
\hline Age & Age & Age in Years & 18 to 93 & $49.15(49)$ & 17.88 \\
\hline \multirow[t]{4}{*}{$\begin{array}{l}\text { Control } \\
\text { variables }\end{array}$} & Sex & Sex (binary) & $\begin{array}{l}1 \text { (Women); } \\
0 \text { (Men) }\end{array}$ & $51.3 \%$ & - \\
\hline & \multirow{3}{*}{$\begin{array}{l}\text { Place of } \\
\text { residence }\end{array}$} & Rural $(n=1200)$ & 1 (yes); 0 (no) & $39.3 \%$ & - \\
\hline & & Suburban $(n=1200)$ & 1 (yes); 0 (no) & $30.5 \%$ & - \\
\hline & & Urban $(n=1200)$ & 1 (yes); 0 (no) & $30.2 \%$ & - \\
\hline
\end{tabular}


party by at least $5 \%$ of the valid sample. Concerning political orientations, those parties are traditionally seen as left to center-left (SPOE, GRUENE), center-right to right $(O E V P)$ and far right $(F P O E)$. Despite their place in the federal council of Austria, NEOS $(n=14)$ and LISTE PILZ aka JETZT $(n=20)$ could not be included as test variables because too few participants stated that they prefer them.

The last dimension includes age to test for hypothesis 4.

Additionally, we included variables to control for gender and place of residence of the respondents as both variables affect news consumption (see Trilling and Schönbach 2013). While Trilling and Schönbach (2013) used different federal states of Austria to measure the place of residence, using the same indicator would result in too small a sample for our analysis. Instead, interviewers noted whether the participant lives (a) in a big city (over 100,000 residents), (b) on the edge or in a suburb of a big city, (c) in a bigger city $(40,000$ to 100,000 residents), (d) in a small or medium town (5000 to under 40,000 residents), (e) in a village or (f) in a single house or farm in the countryside. Due to low case numbers and in accordance with Sørensen (2016), we recoded this question into three categories, namely "urban" (living in a big city or on the edge or in a suburb of a big city), "suburban" (living in a town/city with 5000 to 100,000 residents) and "rural" (living in a village or in a single house or farm in the country).

A descriptive overview on the explanatory variables can be found in Table 3, and a complete overview concerning the independent variables in relation to media usage and repertoires is present in the extensive online appendix (Online Resource 1).

\section{Results and discussion}

Are traditional media still the preferred source of information for Austrians? According to the SSÖ 2018: Yes. TV broadcasting is still the favored source of news for Austrians-74\% of the survey population uses it very often or often-followed by the hardcopies of printed newspapers-close to $60 \%$ use them very often or often. Both online and social media are not as relevant in comparison, with only $26 \%$ and $28 \%$ using them very often or often (see Fig. 2).

Nevertheless, it can be reported that strictly traditional media users are no longer the most common category. The most common repertoire for news consumption among the Austrians surveyed is the hybrid model (see Fig. 3). It amounts to $38 \%$ of the sample and consists of those who use at least some traditional legacy media and some new media. Nonetheless, 36\% - this is more than a third of the sample-still ignore online information, while only $6 \%$ rely strictly on online media. Another $2 \%$ are not actively seeking out any news at all.

These results are in line with the SSÖ 2016 and the Reuters DNR 2019 (Prandner 2019; Sparviero and Trappel 2019). Thus, three studies, the general SSÖ 2016 and 2018 and the specialized Reuters DNR, show that Austria is slightly shifting towards a more digital news-seeking behavior, even if differences in wording, sampling and research agenda make a direct comparison between those projects difficult. However, the singular key difference is the low number of news avoiders in the SSÖ 2018, as the DNR 2019 states that $30 \%$ of the Austrians are (occasional) news-avoiders 
How often do you use the following media to inform yourself about current events?

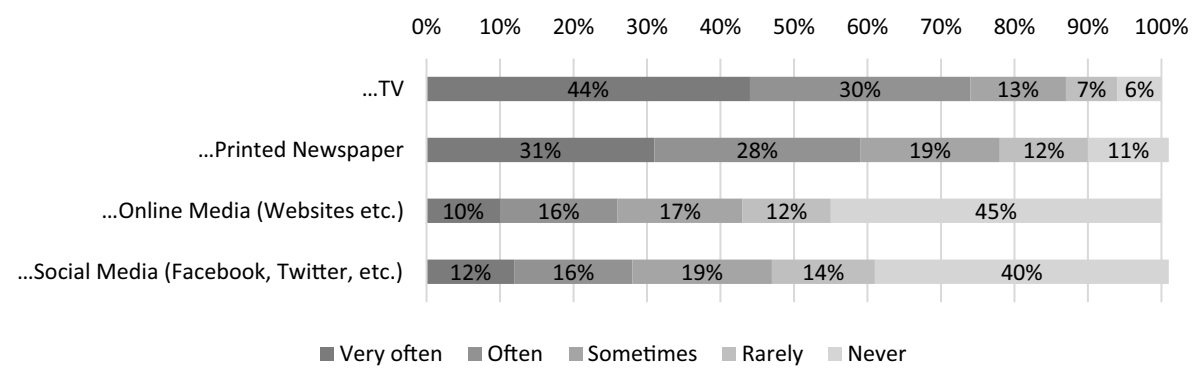

Fig. 2 Information habits of the Austrians-SSÖ 2018 ( $n=1199$; weighted information; rounded values)

\section{News repertoires in Austria}

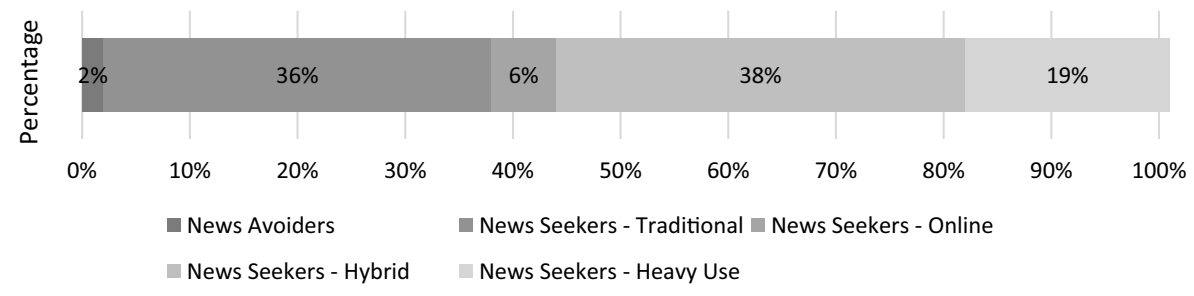

Fig. 3 News repertoires found in the SSÖ 2018 ( $n=1200$; weighted information, rounded values); for classification information, see Fig. 1

(Sparviero and Trappel 2019). The reason for this is tied to the operationalization of the concept. While the DNR identifies intentional news avoidance, for example, people who turn off specific newscasts or do not click on specific news articles, the repertoire classification used in this article is based on the news consumption reported. Even those who are likely to avoid specific news are likely to consume or seek out at least some news.

All explanatory models have good fit values and, in addition, the variances elucidated show that media use can be explained reasonably well. A discussion of the hypotheses follows in the next paragraphs, while Table 4 includes details of the results and coefficients.

The main hypotheses ( $\mathrm{a}$ and $\mathrm{b}$ ) are built upon the premise that inequalities lead to different news repertoires. It is expected that a higher social position would result in an increased likelihood to choose a hybrid or heavy use news repertoire compared to a traditional repertoire. The linear regression models show some empirical support for this hypothesis. Higher personal income is associated with the usage of hybrid and heavy use news repertoires, while individuals with a tertiary education are more likely to use a heavy use news repertoire. Moreover, individuals who are not working are inclined to use an online-only news repertoire, while individuals who are working full-time more often rely on a heavy use news repertoire. No effect can be found only when it comes to the self-attributed social status. 
Table 4 Results of the linear regression models

\begin{tabular}{|c|c|c|c|}
\hline $\begin{array}{l}\text { Dependent variable } \\
(0=\text { traditional news repertoire })\end{array}$ & $\begin{array}{l}\text { Online only news } \\
\text { repertoire }(=1) \\
\text { B }\end{array}$ & $\begin{array}{l}\text { Hybrid news } \\
\text { repertoire }(=1) \\
\beta\end{array}$ & $\begin{array}{l}\text { Heavy use news } \\
\text { repertoire }(=1) \\
\text { B }\end{array}$ \\
\hline \multicolumn{4}{|l|}{ Social Position variables } \\
\hline Social Status & -0.05 & 0.05 & 0.01 \\
\hline \multicolumn{4}{|l|}{ Education $($ ref $=$ primary education or lower $)$} \\
\hline Secondary education & $0.20 * * *$ & 0.03 & 0.04 \\
\hline Tertiary education & 0.07 & 0.02 & $0.10 *$ \\
\hline Income (in $€$ ) & -0.02 & $0.09 *$ & $0.09 *$ \\
\hline \multicolumn{4}{|l|}{ Work per week (ref = not working) } \\
\hline Part-time (1-35h per week) & $-0.16^{* *}$ & -.02 & -0.02 \\
\hline Full-time $(36+\mathrm{h}$ per week) & $-0.14 * * *$ & 0.07 & $0.17 *$ \\
\hline \multicolumn{4}{|l|}{ Social network variables } \\
\hline Trust (Factor) & 0.00 & -0.07 & -0.02 \\
\hline Number of contacts (in persons) & $0.16^{* *}$ & $0.12 *$ & $0.12 *$ \\
\hline \multicolumn{4}{|c|}{ Political orientation (ref $=$ Freedom party-far-right $)$} \\
\hline People's party (center-right to right-wing) & 0.00 & -0.05 & -0.04 \\
\hline Social democrats (center-left to left-wing) & 0.12 & -0.02 & 0.07 \\
\hline Green party (center-left to left-wing) & $0.21 *$ & 0.00 & 0.02 \\
\hline \multicolumn{4}{|l|}{ Age } \\
\hline Age (in years) & $-0.49 * * *$ & $-0.43 * * *$ & $-0.41 * * *$ \\
\hline \multicolumn{4}{|l|}{ Control variables } \\
\hline Sex $($ Female $=1)$ & 0.06 & 0.02 & 0.01 \\
\hline \multicolumn{4}{|l|}{ Place of residence $($ ref $=$ urban $)$} \\
\hline Suburban & -.03 & $0.12 * *$ & $0.12 *$ \\
\hline Rural & -0.02 & -0.08 & -0.07 \\
\hline \multicolumn{4}{|l|}{ Model fit } \\
\hline Adjusted $\mathrm{R}^{2}$ & 0.34 & 0.34 & 0.41 \\
\hline F-Score & $10.9 * * *$ & $19.4 * * *$ & $20.41 * * *$ \\
\hline$n$ & 294 & 537 & 419 \\
\hline
\end{tabular}

Sample sizes of each regression analysis are based on the case numbers of the respective dependent variable plus case numbers of users of traditional news repertoire as the reference group

Hypothesis 1 can be accepted because the non-subjectively attributed measurements influence the outcome in the expected way. The assumptions by Tichenor et al. (1970) match the results, while it can also be shown that workforce integration influences information strategies and patterns (see Hasebrink and Popp 2006; Lindell and Hovden 2018). Furthermore, the findings are in line with the arguments of Kalogeropoulos and Nielsen (2018), who debated for a deeper relationship between economic position and news seeking. In their study on the UK, they saw a more disparate distribution of information in society than from income. However, not only is their research based on a different mediascape, but they used Reuters DNR data and could not model their assumptions on the level of individuals. They had to go for auxiliary data—based on the Gini coefficient—-to support their argument. In the 
case of the SSÖ 2018, this is not necessary as it included the necessary individuallevel data.

Regarding hypothesis 2, our results partly support previous studies. Based on our results, frequent social contacts are associated with the inclusion of online media into one's news repertoire (c). This result is robust in our analyses since this effect can be found for the usage of online-only, hybrid, and heavy use news repertoires compared to traditional news repertoires. It is in accordance with Bennet (2012) and $\mathrm{Li}$ et al. (2017). However, unlike Bennett (2012) and $\mathrm{Li}$ et al. (2017), we find no effect of social trust on the usage of media repertoires ( $a$ and $b$ ).

Hypothesis 3 was not supported by our results. Voters of the left-wing green party rely on online-only news repertoires more often than on traditional news repertoires compared to voters of all other major parties. This result is a direct contradiction to previous international studies (Esser et al. 2017, p. 375; Lindell and Hovden 2018, p. 652). However, it bears some similarities to the findings of Trilling and Schönbach (2013, p. 945) mentioned previously, who argued that right-wing users are more likely to be predominantly tabloid readers - a group that would be part of our traditional media repertoire.

Potential explanations for this may be the strong online presence of left-wing publications such as Der Standard and the missing differentiation between online and social media users in the repertoire approach chosen. Further research is necessary here as the sample size and the structure of the variables found within the dataset are not suitable to build more detailed repertoires.

The strongest effects in our models, however, are in accordance with the fourth hypothesis, namely, that younger Austrians are more likely to use an online-only repertoire and older ones a more traditional repertoire. Younger Austrians report that they are more likely to use online-only, hybrid and heavy use news repertoires than traditional news repertoires. This also implies that Bennett and Iyengar (2008) are correct in their statement that younger individuals are less likely to discover news outside their spheres of interest than older ones, as they are using more personalized offerings.

While gender does not affect media usage, Austrians from suburban regions more often report using hybrid or heavy use news repertoires. This ambivalent result regarding the place of residence is also supported by the findings of Trilling and Schönbach (2013), although their results related to the different federal states in Austria. However, since we could include place of residence only as a control variable, we have no clear explanation for this exploratory result and rely on future research for a more in-depth analysis regarding the effect of the place of residence on media usage.

Overall, our data suggest that (a) higher income is associated with a hybrid or heavy use news repertoire. In the case of a heavy use repertoire, this is also true for tertiary education (supporting hypotheses 1a and b); (b) a higher number of social contacts lead to the inclusion of online and social media in one's news repertoire (supporting hypothesis 2c); (c) voting for the green party is associated with an onlineonly news repertoire (contradicting hypothesis 3 ); and (d) younger individuals are more likely to use an online-only repertoire (supporting hypothesis 4). However, the self-reported social position and social trust show no relation with media usage. 
Altogether, the social inequalities discussed have a substantive effect on the media repertoire used.

\section{Conclusion: The Austrians' news repertoires are inherently driven by resources and technological adaption}

This article started with the assumption that the diversification of the mediascape must take social inequalities into account, allowing an insight into how news reaches society (Lindell 2018). The emergence of digital media has led to an adoption process and audiences have responded to this process (Bjur et al. 2014).

We are currently beginning to understand how people combine different media into encompassing repertoires that convey different strategies-intentional or not-to stay informed. This knowledge is of relevance as society realizes that the transition to an increasingly digital news landscape leads to a number of complicated and hard to resolve paradoxes (Peters and Schrøder 2018, p. 1085). The idea of an enlightened and active public sphere that thrives on information remains an ideal. On the contrary, participatory social media has resulted in an enduring discussion regarding highly selective information habits and even news avoidance (Fletcher and Nielsen 2017).

Despite the fact that the SSÖ 2018 only includes broad information on media usage patterns, it shows that these fears are not necessarily justified. Austrians still rely mostly on traditional media, based on journalistic work routines and the experienced professional guidelines of reporting. Only $6 \%$ cut out traditional media from their news repertoires. A limited number of individuals could be classified as news avoiders: Less than $2 \%$ are not regularly seeking out news. Both of those outcomes are in line with the results from the SSÖ 2016 (Prandner 2019).

Social inequalities seem to have a profound impact on news consumption. People with higher incomes seem to prefer diversified news repertoires, while those who are less integrated into the job market gravitate towards an online-only repertoire. In addition, those who lack social contacts are also more likely to only use traditional media to inform themselves. Yet, the subjectively reported social position of an individual does not factor into the results in a significant way.

Additionally, the effects found regarding political orientation and social inclusion were not in line with previous studies or significant. This hints at the fact that even FPOE supporters are not tuning out from traditional news.

Overall results indicate that online-only users are a small minority and the thesis that Austrians are mostly using new media as additional information sources can be accepted for now. Furthermore, the responses illustrate that Austrians are highly interested in news, even if social inequalities seem to influence the news-seeking behavior.

Finally, it is of utmost relevance to acknowledge that some international trends could not be confirmed via the SSÖ 2018 dataset. Some of these findings may be tied to the limitations of a social survey, for example, not being able to collect information on media titles. Nevertheless, the results show that media usage and information patterns are deeply ingrained into national structures and media landscapes. Austria 
as a country is defined by a strong public service broadcaster - the $O R F$ - that also maintains a strong online media presence and encourages cross-media use. On the other hand, fringe actors, such as Der Standard, and long-standing giants, such as Die Krone, were able to find an online audience and enter the digital market. However, digital-only content providers that may cover different topics (as argued by Hasebrink and Domayer 2012; Reagan 1996) are uncommon for the Austrian mediascape and, thus, news seekers are inherently motivated to stay informed via cross-media strategies and add different media rather than replacing them (Hasebrink et al. 2015, p. 450).

Nevertheless, future survey projects should include more detailed information on the media titles actually consumed and potentially provide respondents with the opportunity to name their primary news sources. This information would make it possible to match and compare insights gained in social surveys with either in-depth interviews or specialized survey programs, such as like the Reuters Study on Digital News, in a more meaningful way. This would result in a deeper understanding of how information behavior in an ever-changing media landscape and societal inequalities relate to each other.

Funding Open access funding provided by Johannes Kepler University Linz.

Open Access This article is licensed under a Creative Commons Attribution 4.0 International License, which permits use, sharing, adaptation, distribution and reproduction in any medium or format, as long as you give appropriate credit to the original author(s) and the source, provide a link to the Creative Commons licence, and indicate if changes were made. The images or other third party material in this article are included in the article's Creative Commons licence, unless indicated otherwise in a credit line to the material. If material is not included in the article's Creative Commons licence and your intended use is not permitted by statutory regulation or exceeds the permitted use, you will need to obtain permission directly from the copyright holder. To view a copy of this licence, visit http://creativecommons.org/licenses/by/4. $0 /$.

\section{References}

Aalberg, Toril, Arild Blekesaune, and Eiri Elvestad. 2013. Media choice and informed democracy: toward increasing news consumption gaps in Europe? International Journal of Press/Politics 18(3):281-303. https://doi.org/10.1177/1940161213485990.

Andersen, Robert. 2008. Modern methods for robust regression. Quantitative applications in the social sciences, no. 07-152. Los Angeles: SAGE.

Bacher, Johann, Alfred Grausgruber, Max Haller, Franz Höllinger, Dimitri Prandner, and Roland Verwiebe (eds.). 2019. Sozialstruktur und Wertewandel in Österreich: Trends 1986-2016. Wiesbaden: Springer. https://doi.org/10.1007/978-3-658-21081-6.

Bennett, W. Lance. 2012. The personalization of politics: political identity, social media, and changing patterns of participation. Annals of the American Academy of Political and Social Science 644(1):20-39. https://doi.org/10.1177/0002716212451428.

Bennett, W. Lance, and Shanto Iyengar. 2008. A new era of minimal effects? The changing foundations of political communication. Journal of Communication 58(4):707-731. https://doi.org/10.1111/j.14602466.2008.00410.x.

Berner, Jessica S., Mikael Rennemark, Claes Jogréus, and Johan Berglund. 2013. Factors associated with change in internet usage of Swedish older adults (2004-2010). Health Informatics Journal 19(2):152-162. https://doi.org/10.1177/1460458212462151.

Bjur, Jakob, Kim Schrøder, Uwe Hasebrink, Cédric Courtois, Hanna Adoni, and Hillel Nossek. 2014. Cross-media use: unfolding complexities in contemporary Audiencehood. In Audience transformations: shifting audience positions in late modernity, ed. Nico Carpentier, Kim Schrøder, and Lawrie Hallet, 15-29. London: Routledge. 
Calvo-Armengol, Antoni, and Matthew O. Jackson. 2004. Social networks in determining employment: patterns, dynamics, and inequality. Microeconomics, university library of Munich, Germany, p. 37. https://EconPapers.repec.org/RePEc:wpa:wuwpmi:0211007. Accessed 18 Oct 2020.

Carmo, M. Renato. 2017. Reducing inequalities, 1st edn., New York: Springer.

Chadwick, Andrew, James Dennis, and Amy P. Smith. 2016. Politics in the age of hybrid media: power, systems, and media logics. In The Routledge companion to social media and politics, ed. Axedl Bruns, Gunn Enli, Eli Skogerbo, Anders O. Larsson, and Christian Christensen, 7-22. New York: Routledge.

Cohen, Jacob. 1968. Multiple regression as a general data-analytic system. Psychological Bulletin 70(6, Pt.1):426-443. https://doi.org/10.1037/h0026714.

Da Silva, T. Marisa, Maria J. Brites, Rita Figueiras, C. Santos Silvio, Ines Amaral, Lidia S.B. Maropo, Pedro Jeronimo, Santo P. Espirito, and Liliana Pacheco. 2017. Between traditional and social media: news repertoires in Portugal. Participations-Journal of Audience and Reception Studies 14(2):283-300.

Newman, Nick, and David A. L. Levy. 2014. Reuters institute news report 2014. Oxford: University of Oxford.

Dilliplane, Susana. 2011. All the news you want to hear: the impact of partisan news exposure on political participation. Public Opinion Quarterly 75(2):287-316. https://doi.org/10.1093/poq/nfr006.

Edgerly, Stephanie, Emily K. Vraga, Leticia Bode, Kjerstin Thorson, and Esther Thorson. 2018. New media, new relationship to participation? A closer look at youth news repertoires and political participation. Journalism \& Mass Communication Quarterly 95(1):192-212. https://doi.org/10.1177/ 1077699017706928.

Eisenegger, Mark. 2019. Hauptbefunde - Umbau der Schweizer Medienöffentlichkeit. Qualität der Medien 10:9-26.

Eisenegger, Mark, and Jörg Schneider. 2016. Wie Mediennutzer in die Welt schauen: Die Newsrepertoires der Schweizerinnen und Schweizer und ihre Themenagenden. Basel: Schwabe. https://public. ebookcentral.proquest.com/choice/publicfullrecord.aspx? $\mathrm{p}=4753260$.

Elvestad, Eiri, Arild Blekesaune, and Toril Aalberg. 2014. The polarized news audience? A longitudinal study of news-seekers and news-avoiders in Europe (july 22, 2014). Paper presented at the APSA, Washington DC. https://doi.org/10.2139/ssrn.2469713.

Engesser, Sven, Nicole Ernst, Frank Esser, and Florin Büchel. 2017. Populism and social media: how politicians spread a fragmented ideology. Information, Communication \& Society 20(8):1109-1126. https://doi.org/10.1080/1369118X.2016.1207697.

Esser, Frank, Agnieszka Stepinska, and David N. Hopmann. 2017. Populism and the media. Cross-national findings and perspectives. In Populist political communication in Europe, ed. Toril Aalberg, Frank Esser, Carsten Reinemann, Jesper Strömbäck, and Claes H. de Vreese, 365-380. London: Routledge.

Fletcher, Richard, and Rasmus K. Nielsen. 2017. Are news audiences increasingly fragmented? A crossnational comparative analysis of cross-platform news audience fragmentation and duplication. Journal of Communication 67(4):476-498. https://doi.org/10.1111/jcom.12315.

Giglietto, Fabio, Laura Iannelli, Augusto Valeriani, and Luca Rossi. 2019. "Fake news" is the invention of a liar: how false information circulates within the hybrid news system. Current Sociology 67(4):625-642. https://doi.org/10.1177/0011392119837536.

Gil de Zúñiga, Homero, Brian Weeks, and Alberto Ardèvol-Abreu. 2017. Effects of the news-finds-me perception in communication: social media use implications for news seeking and learning about politics. Journal of Computer-Mediated Communication 22(3):105-123. https://doi.org/10.1111/jcc4.12185.

Hadler, Markus, Franz Höllinger, and Johanna Muckenhuber. 2019. Social Survey Austria 2018 (SUF edition). AUSSDA Dataverse, V3, (Last access: 30 January 2020). https://doi.org/10.11587/ERDG3O.

Hallin, Daniel C., and Paolo Mancini. 2004. Comparing media systems: three models of media and politics. Communication, society, and politics. Cambridge, New York: Cambridge University Press.

Han, Kyung Joon. 2016. Income inequality and voting for radical right-wing parties. Electoral Studies 42:54-64. https://doi.org/10.1016/j.electstud.2016.02.001.

Hasebrink, Uwe, and Hanna Domeyer. 2012. Media media repertoires as patterns of behavior and as meaningful practices: a multimethod approach to media use in converging media environments. Participations. Journal of Audience \& Reception Studies 9(2):757-779.

Hasebrink, Uwe, and Jutta Popp. 2006. Media repertoires as a result of selective media use. A conceptual approach to the analysis of patterns of exposure. Communications https://doi.org/10.1515/ COMMUN.2006.023. 
Hasebrink, Uwe, Klaus Bruhn Jensen, Hilde van den Bulck, Sascha Hölig, and Pieter Maeseele. 2015. Changing patterns of media use across cultures: a challenge for longitudinal research. International Journal of Communication 9:435-457.

Hepp, Andreas, and Uwe Hasebrink. 2014. Human interaction and communicative figurations: the transformation of Mediatized cultures and societies. In Mediatization of communication, ed. Knut Lundby, 249-272. Berlin, Boston: De Gruyter Mouton.

Hille, Sanne, and Piet Bakker. 2013. I like news. Searching for the "holy grail" of social media: the use of Facebook by Dutch news media and their audiences. European Journal of Communication 28(6):663-680. https://doi.org/10.1177/0267323113497435.

Hofmann, Julia. 2016. Abstiegsangst und Tritt nach unten? Die Verbreitung von Vorurteilen und die Rolle sozialer Unsicherheit bei der Entstehung dieser am Beispiel Österreichs. In Solidaritätsbrüche in Europa. Europa - Politik - Gesellschaft, ed. Wolfgang Aschauer, Elisabeth Donat, and Julia Hofmann. Wiesbaden: Springer VS. https://doi.org/10.1007/978-3-658-06405-1_11.

Kalogeropoulos, Antonis, and Rasmus K. Nielsen. 2018. FACTSHEET-social inequalities in news consumption. Oxford: University of Oxford.

Kalogeropoulos, Antonis, Samuel Negredo, Ike Picone, and Rasmus Kleis Nielsen. 2017. Who shares and comments on news?: a cross-national comparative analysis of Online and social media participation. Social Media + Society 3(4):205630511773575. https://doi.org/10.1177/2056305117735754.

Kirchhoff, Susanne, and Dimitri Prandner. 2016. Bausteine des journalistischen Selbstbilds: Überlegungen zum Zusammenhang von Habitus, Praxis und Feldstrukturen im österreichischen Journalismus. In Medien-Arbeit im Wandel, ed. Jeffrey Wimmer, Maren Hartmann, 93-114. Wiesbaden: Springer. https://doi.org/10.1007/978-3-658-10912-7_5.

Kuhn, Theresa, Erika van Elsas, Armen Hakhverdian, and Wouter van der Brug. 2016. An ever wider gap in an ever closer union: rising inequalities and Euroscepticism in 12 west European democracies, 1975-2009. Socio-Economic Review 14(1):27-45. https://doi.org/10.1093/ser/mwu034.

Li, Shupin, Lauri Hietajärvi, Tuire Palonen, Katariina Salmela-Aro, and Kai Hakkarainen. 2017. Adolescents' social networks: exploring different patterns of socio-digital participation. Scandinavian Journal of Educational Research 61(3):255-274. https://doi.org/10.1080/00313831.2015.1120236.

Lin, Nan. 2000. Inequality in social capital. Contemporary Sociology 29(6):785. https://doi.org/10.2307/ 2654086.

Lindell, Johan. 2018. Distinction recapped: digital news repertoires in the class structure. New Media \& Society 20(8):3029-3049. https://doi.org/10.1177/1461444817739622.

Lindell, Johan, and Jan Fredrik Hovden. 2018. Distinctions in the media welfare state: audience fragmentation in post-egalitarian Sweden. Media, Culture \& Society 40(5):639-655. https://doi.org/10.1177/ 0163443717746230.

Livingstone, Sonia. 2013. The participation paradigm in audience research. Communication Review 16(1-2):21-30. https://doi.org/10.1080/10714421.2013.757174.

Long, J. Scott, and Jeremy Freese. 2006. Regression models for categorical dependent variables using stata, 2nd edn., College Station: StataCorp LP.

Lynch, Julia. 2019. Populism, partisan convergence, and mobilization in western Europe. Polity 51(4): 668-677. https://doi.org/10.1086/705569.

Magin, Melanie, and Birgit Stark. 2011. Österreich - Land ohne Leuchttürme? Qualitätszeitungen im Spannungsfeld zwischen publizistischer Leistung und strukturellen Zwängen. In Krise der Leuchttürme öffentlicher Kommunikation, ed. Roger Blum, Heinz Bonfadelli, Kurt Imhof, and Otfried Jarren, 97-114. Wiesbaden: VS. https://doi.org/10.1007/978-3-531-93084-8_7.

MediaAnalyse. 2019. MA 18/19. https://www.media-analyse.at/table/3194. Accessed 30-01-2020.

Neuman, W. Russell, Marion R. Just, and Ann N. Crigler. 1992. Common knowledge: news and the construction of political meaning. American politics and political economy series. Chicago: University of Chicago Press.

Newman, Nick, Richard Fletcher, Antonis Kalogeropoulos, and David A. Levy. 2018. Reuters institute digital news report 2018. Vol. 2018. Oxford: Reuters Institute for the Study of Journalism.

Nielsen, K. Rasmus, and Sarah Anne Ganter. 2018. Dealing with digital intermediaries: a case study of the relations between publishers and platforms. New Media \& Society 20(4):1600-1617. https://doi.org/ 10.1177/1461444817701318.

Oe, W. 2019. Österreichische Webanalyse - BASIC - Nicht Werbeträger. https://report.oewa.at/basic/ online-angebote. Accessed 30 Jan 2020.

Ohlsson, Jonas, Johan Lindell, and Sofia Arkhede. 2017. A matter of cultural distinction: news consumption in the online media landscape. European Journal of Communication 32(2):116-130. https://doi. org/10.1177/0267323116680131. 
Palfrey, John G., and Urs Gasser. 2011. Born digital: understanding the first generation of digital natives. New York: Basic Books.

Peters, Chris, and Kim Christian Schrøder. 2018. Beyond the here and now of news audiences: a processbased framework for investigating news repertoires. Journal of Communication 68(6):1079-1103. https://doi.org/10.1093/joc/jqy060.

Prandner, Dimitri. 2019. Politische Informationsrepertoires - Zwischen Informieren und Vertrauen. In Sozialstruktur und Wertewandel in Österreich, ed. Johann Bacher, Alfred Grausgruber, Max Haller, Franz Höllinger, Dimitri Prandner, and Roland Verwiebe, 411-438. Wiesbaden: Springer. https://doi. org/10.1007/978-3-658-21081-6_17.

Prior, Markus. 2005. News vs. entertainment: how increasing media choice widens gaps in political knowledge and turnout. American Journal of Political Science 49(3):577-592. https://doi.org/10.1111/j. 1540-5907.2005.00143.x.

Reagan, Joey. 1996. The "repertoire" of information sources. Journal of Broadcasting \& Electronic Media 40(1):112-121. https://doi.org/10.1080/08838159609364336.

Schmuck, Desirée, Jörg Matthes, and Hajo Boomgaarden. 2016. Austria: candidate-centered and anti-immigrant right-wing populism. In Populist political communication in europe, ed. Toril Aalberg, Fank Esser, Carste Reinemann, Jesper Strömäck, and Claes H. de Vreese, 95-108. London: Routledge.

Schneider, Jörg, and Mark Eisenegger. 2019. Der Bedeutungsverlust traditioneller Newsmedien und die Entstehung neuer Nutzungsmuster - wie die Digitalisierung Newsrepertoires verändert. In Qualität der Medien, ed. fög-Forschungsinstitut Öffentlichkeit und Gesellschaft, 27-45. Basel: Schwabe.

Schulz, Anne, David Levy, and Rasmus K. Nielsen. 2019. Old, educated, and politically diverse: the audience of public service news. Oxford: University of Oxford.

Seufert, Wolfgang, and Claudia Wilhelm. 2013. Wie stark verdrängen oder ergänzen sich (neue und alte) Medien? Medien \& Kommunikationswissenschaft 61(4):568-593. https://doi.org/10.5771/1615634x-2013-4-568.

Skovsgaard, Morten, and Kim Andersen. 2020. Conceptualizing news avoidance: towards a shared understanding of different causes and potential solutions. Journalism Studies 21(4):459-476.

Sobieraj, Sarah, and Jeffrey M. Berry. 2011. From incivility to outrage: political discourse in Blogs, talk radio, and cable news. Political Communication 28(1):19-41. https://doi.org/10.1080/10584609.2010. 542360.

Song, Hyunjin, Dominic Nyhuis, and Hajo Boomgaarden. 2019. A network model of negative campaigning: the structure and determinants of negative campaigning in multiparty systems. Communication Research 46(2):273-294. https://doi.org/10.1177/0093650217712596.

Sørensen, Jens F.L. 2016. Rural-Urban differences in bonding and bridging social capital. Regional Studies 50(3):391-410. https://doi.org/10.1080/00343404.2014.918945.

Sparviero, Sergio, and Josef Trappel. 2017. Austria. In Reuters institute digital news report 2017, ed. Nick Newman, Richard Fletcher, Antonis Kalogeropoulos, and Rasmus K. Nielsen, 55-57. Oxford: University of Oxford.

Sparviero, Sergio, and Josef Trappel. 2019. Austria. In Reuters institute digital news report 2019, ed. Nick Newman, Richard Fletcher, Antonis Kalogeropoulos, and Rasmus K. Nielsen, 70-72. Oxford: University of Oxford.

Stark, Birgit. 2007. Programmauswahl in digitalen Fernsehwelten: Der EPG als Gatekeeper? M\&K Medien \& Kommunikationswissenschaft 55(2):223-246. https://doi.org/10.5771/1615-634x-2007-2-223.

Strömbäck, Jesper. 2017. News seekers, news avoiders, and the mobilizing effects of election campaigns: comparing election campaigns for the national and the European parliaments. International Journal of Communication 11:237-258.

Stroud, Natalie Jomini. 2011. Niche news. Oxford: Oxford University Press. https://doi.org/10.1093/ acprof:oso/9780199755509.001.0001.

Taneja, Harsh, James G. Webster, Edward C. Malthouse, and Thomas B. Ksiazek. 2012. Media consumption across platforms: identifying user-defined repertoires. New Media \& Society 14(6):951-968. https://doi.org/10.1177/1461444811436146.

Tichenor, Phillip G., George A. Donohue, and Clarice N. Olien. 1970. Mass media flow and differential growth in knowledge. Public Opinion Quarterly 34(2):159. https://doi.org/10.1086/267786.

Trilling, Damian, and Klaus Schönbach. 2013. Patterns of news consumption in Austria: how fragmented are they? International Journal of Communication 7:929-953.

Van Dijck, José. 2009. Users like you? Theorizing agency in user-generated content. Media, Culture \& Society 31(1):41-58. https://doi.org/10.1177/0163443708098245.

Webster, James G. 2014. The Marketplace of Attention: How Audiences Take Shape in a Digital Age. Cambridge, MA: MIT Press. 
Wolf, Cornelia, and Anna Schnauber. 2015. News consumption in the mobile era: the role of mobile devices and traditional journalism's content within the user's information repertoire. Digital Journalism 3(5):759-776. https://doi.org/10.1080/21670811.2014.942497.

Wolfsfeld, Gadi, Moran Yarchi, and Tal Samuel-Azran. 2016. Political information repertoires and political participation. New Media \& Society 18(9):2096-2115. https://doi.org/10.1177/1461444815580413.

Yuan, Elaine. 2011. News consumption across multiple media platforms: a repertoire approach. Information, Communication \& Society 14(7):998-1016. https://doi.org/10.1080/1369118X.2010.549235.

Zillien, Nicole, and Eszter Hargittai. 2009. Digital distinction: status-specific types of Internet usage. Social Science Quarterly 90(2):274-291. https://doi.org/10.1111/j.1540-6237.2009.00617.x.

Dimitri Prandner is a sociologist and communication scientist. He works as post-doctoral researcher at the Empirical Social Research Unit of the Johannes Kepler University Linz and as a lecturer at the Department of Political Science and Sociology at the Paris Lodron University Salzburg. He is part of the Social Survey Austria (SSÖ) research group and involved in the ongoing development of AUSSDA - The Austrian Social Science Data Archive. Recent projects are in the field of migration studies and Prandner is involved in setting up the European EMM Survey Registry. His main research interests are the sociology of news and social science research methods.

Christoph Glatz works as a research associate at the Center for Social Research at the Karl-FranzensUniversity Graz, where he supports the implementation and evaluation of the Social Survey Austria. His research focus is quality of life. 